\title{
Water Quality in Organic Systems
}

\author{
Cynthia A. Cambardella ${ }^{1}$, Kathleen Delate ${ }^{2} \&$ Dan B. Jaynes ${ }^{1}$ \\ ${ }^{1}$ USDA-ARS National Laboratory for Agriculture and the Environment, Ames, IA, USA \\ ${ }^{2}$ Iowa State University, Departments of Horticulture and Agronomy, Ames, IA, USA \\ Correspondence: Cynthia A. Cambardella, USDA-ARS National Laboratory for Agriculture and the \\ Environment, 2110 Univerisity Blvd., Ames, IA, USA. Tel: 1-515-294-2921. E-mail: \\ cindy.cambardella@ars.usda.gov
}

Received: February 23, 2015 Accepted: April 17, 2015 Online Published: June 20, 2015

doi:10.5539/sar.v4n3p60 URL: http://dx.doi.org/10.5539/sar.v4n3p60

\begin{abstract}
Non-point source contamination is a major water quality concern in the upper Midwestern USA, where plant nutrients, especially $\mathrm{NO}_{3}-\mathrm{N}$, are susceptible to leaching due to extensive subsurface draining of the highly productive, but poorly drained, soils found in this region. Environmental impacts associated with intensive mineral fertilization in conventional production have encouraged producers to investigate organic methods. The USDA-ARS Organic Water Quality (OWQ) experiment, established in 2011, compares organic (C-S-O/A-A) and conventional (C-S) crop rotations and an organic pasture (bromegrass, fescue, alfalfa, white clover) system. Thirty fully-instrumented, subsurface-drained plots $(30.5 \mathrm{~m} \times 30.5 \mathrm{~m})$ laid out in a randomized block design with 5 field replications, isolate subsurface drainage from each plot and permit comparison of treatment effects on subsurface drainage water flow and nutrient concentrations. Objectives for this study were to quantify growing season subsurface drainage water flow, $\mathrm{NO}_{3}-\mathrm{N}$ concentrations, and $\mathrm{NO}_{3}-\mathrm{N}$ loads for conventional and organic grain cropping systems from 2012-2014. Temporal patterns of subsurface drainage water flux were similar for all cropping systems for all years, except for the pasture system in 2012 and subsurface drainage water N concentrations were highest in the conventional C-S system except for the early spring 2012. Subsurface drainage water $\mathrm{N}$ loading loss for the entire 3-year period from the conventional C-S system $\left(79.2 \mathrm{kgN} \mathrm{ha}^{-1}\right)$ was nearly twice as much as the $\mathrm{N}$ loss from the organic C-S-O/A-A system $\left(39.9 \mathrm{kgN} \mathrm{ha}^{-1}\right)$; the pasture system $(16.5$ $\mathrm{kgN} \mathrm{ha}^{-1}$ ) lost the least amount of $\mathrm{N}$ over the 3 years. Results of this study suggest that organic farming practices, such as the application of composted animal manure and the use of forage legumes and green manures within extended cropping rotations, can improve water quality in Midwestern subsurface-drained landscapes.
\end{abstract}

Keywords: organic farming systems, water quality, subsurface drainage, nitrate leaching

\section{Introduction}

The Midwestern U.S. is one of the most productive agricultural regions in the world, but conventional agricultural management of this land has led to serious, negative environmental consequences. Nitrate contamination of surface waters, primarily from the discharge of subsurface drainage water and shallow ground water, is causing increasing concern because a significant proportion of the nitrate in the Mississippi River comes from agricultural land in the Midwest (Goolsby et al., 1999; Jaynes et al., 1999) and this nitrate contributes significantly to hypoxia in the Gulf of Mexico (Rabalais et al., 1996). Environmental impacts associated with intensive mineral fertilization in conventional production (Pimentel et al., 1989) have encouraged producers to investigate organic methods. Increasingly, organic producers are being asked to provide evidence that organic farming practices, such as the application of composted animal manure and the use of forage legumes and green manures within extended cropping rotations, are environmentally benign.

Water quality in the Midwestern USA: Non-point source contamination is a major water quality concern in the upper Midwest, where plant nutrients, especially $\mathrm{NO}_{3}-\mathrm{N}$, are susceptible to leaching due to extensive subsurface draining of the highly productive, but poorly drained, soils found in this region (Gast et al., 1978; Baker \& Johnson, 1981; Randall et al., 1997; Zhao et al., 2001; Magner et al., 2004). The drinking water standard for $\mathrm{NO}_{3}-\mathrm{N}$ concentration in the USA is $10 \mathrm{mg} \mathrm{NO}_{3}-\mathrm{N}$ liter $^{-1}$. Nitrogen fertilizer management alone will not be successful in lowering drainage water $\mathrm{NO}_{3}-\mathrm{N}$ concentrations to meet water quality standards (Dinnes et al, 2002). Jaynes et al. (2001) found that $\mathrm{NO}_{3}-\mathrm{N}$ concentrations of drainage water were greater than $10 \mathrm{mg} \mathrm{\textrm {L } ^ { - 1 }}$ at N 
fertilizer rates that were substantially below the economic optimum $\mathrm{N}$ fertilizer rates for corn grain production. Subsurface drainage water $\mathrm{NO}_{3}-\mathrm{N}$ concentrations were above $10 \mathrm{mg} \mathrm{L}^{-1}$ even following a soybean crop when no $\mathrm{N}$ fertilizers were applied the previous spring (Cambardella et al., 1999; Jaynes et al., 2001).

Water quality in organic systems: The scientific literature on water quality and water flux in organic systems is very limited. Many of the published studies in the past decade use nutrient concentration data obtained from lysimeters to estimate $\mathrm{NO}_{3}$-N loss (Biro et al., 2002; Askegaard et al., 2005; Pimentel et al., 2005; Stopes et al., 2005; Loges et al., 2008; Hatch et al., 2010). Estimates of water flux are estimated mathematically (Askegaard et al., 2005; Hatch et al., 2010), modeled (Hansen et al., 2000; Loges et al., 2008) or ignored (Biro et al., 2002; Pimentel et al., 2005).

On-farm studies conducted in England compared $\mathrm{NO}_{3}-\mathrm{N}$ leaching losses from organic and conventional farms in the arable and grass phase of the rotations. Nitrate losses following arable crops averaged 47 and $58 \mathrm{~kg} \mathrm{~N}^{-1} \mathrm{for}^{-1}$ the organic and conventional systems, respectively. Nitrate losses during the organic grass phase, which included winter plowing, were similar $\left(45 \mathrm{~kg} \mathrm{~N}^{-1}\right)$ to the grass phase of conventional grass-arable rotations $(50 \mathrm{~kg} \mathrm{~N}$ $\mathrm{ha}^{-1}$ ) (Stopes et al., 2002). An organically-managed oil seed pumpkin (Curcurbit pepo)-potato (Solanum tubeosum) rotation in Hungary resulted in significantly lower cumulative (over 200 consecutive days) $\mathrm{NO}_{3}-\mathrm{N}$ load ( $\sim 20 \mathrm{mg} \mathrm{NO}_{3}-\mathrm{N}$ per lysimeter) than a conventionally-managed rotation pumpkin-potato rotation $(\sim 280 \mathrm{mg}$ $\mathrm{NO}_{3}-\mathrm{N}$ per lysimeter) (Biro et al., 2005).

A simulation study of two Minnesota watersheds comparing conventional with alternative cropping systems that included perennial crops concluded that adding perennials to the crop rotation reduced $\mathrm{N}$ and $\mathrm{P}$ loads (Boody et al., 2005). A study conducted in southwest Minnesota examined effects of both alternative (including organic management) and conventional farming practices on $\mathrm{NO}_{3}-\mathrm{N}$ loss in subsurface drainage water from glacial till soils (Oquist et al., 2007). Results indicate that alternative farming practices reduced subsurface drainage discharge by $41 \%$ compared with conventional practices. Flow-weighted mean $\mathrm{NO}_{3}-\mathrm{N}$ concentrations during subsurface drain flow were 8.2 and $17.2 \mathrm{mg} \mathrm{L}^{-1}$ under alternative and conventional farming practices, respectively.

The long-term goal of this research is to evaluate the environmental impact of organic farming systems, including effects on water quality, water retention, carbon sequestration, and soil health. Specific objectives for this study were to quantify growing season subsurface drainage water flow, $\mathrm{NO}_{3}-\mathrm{N}$ concentrations, and $\mathrm{NO}_{3}-\mathrm{N}$ loss for a conventional C-S rotation, an organic C-S-O/A-A rotation, and an organic pasture from 2012-2014.

\section{Materials and Methods}

Experimental Design: The USDA-ARS Organic Water Quality (OWQ) experimental site is located at the ISU Agronomy Research Farm, near Boone, Iowa, on the Clarion-Nicollet-Webster soil association. Thirty-year average annual rainfall and temperature for Boone IA are $97.4 \mathrm{~cm}$ and $8.81{ }^{\circ} \mathrm{C}$, respectively (NOAA National Climate Data Center, verified 2/13/15). Soils at the site are mapped as Clarion (fine-loamy, mixed, mesic Cumulic Hapludoll), Canisteo (fine-loamy, mixed (calcareous), mesic Typic Haplaquoll), and Webster (fine-loamy, mixed, mesic Typic Haplaquoll). The field site was cropped to a conventionally managed corn (Zea mays L.)-soybean [Glycine max (L.) Merr.] (C-S) rotation prior to planting an oat (Avena sativa L.) /alfalfa (Medicago sativa L.) crop in 2006. No agricultural chemicals or fertilizers have been applied to the field since fall 2006. The 4.1-ha site consists of 30 field plots $(30.5 \mathrm{~m} \times 30.5 \mathrm{~m})$ laid out in a randomized complete block design with five replications. Installation of subsurface drainage lines under each plot and instrumentation to collect water samples and monitor subsurface drainage water flow and nutrient loss, including flow barriers and sump pits, was completed in September 2011. A fully-instrumented weather station and tipping bucket rain gauge are located immediately adjacent to the field plots. Weather data, including ambient temperature and precipitation, are recorded every hour and downloaded for easy access through laboratory computers. Three cropping systems were established in the spring of 2012. Each phase of the cropping system is present every year and identical, non-GMO varieties are planted at the same seeding rate in conventional and organic plots. Experimental treatments include an organically managed corn-soybean-oat/alfalfa-alfalfa (C-S-O/A-A) rotation, an organically managed perennial pasture system (bromegrass, Bromus; fescue, Festuca; alfalfa; and white clover, Trifolium repens) and a conventionally managed C-S rotation. Results from a companion long-term experimental site located in south central IA USA, show that this 4-year organic rotation increased soil quality variables (for example, soil organic carbon, total $\mathrm{N}$, and $\mathrm{N}$ mineralization potential) critical for minimizing nutrient leaching potential and optimizing water cycling and retention (Delate \& Cambardella, 2004). The fully-instrumented, subsurface-drained research site provides the opportunity to conduct long-term, statistically robust experiments using production-scale farm machinery to assess environmental, soil and agronomic response 
for the extended cropping rotations typically used in organic agriculture.

Agronomic practices: The organic corn and oat plots are amended with composted dairy cattle manure in early spring (March 15, 2012; April 25, 2013; April 14, 2014); compost is immediately incorporated using a chisel plow. Compost application rate is based on total $\mathrm{N}$ in the compost at a target rate of $171 \mathrm{kgN} / \mathrm{ha}$ to the organic corn plots and $57 \mathrm{kgN} / \mathrm{ha}$ to the organic oat plots. Corn and soybean were planted on May 22 in 2012, May 15 in 2013, and May 29 in 2014. Grain yield is measured using a weigh wagon. Alfalfa is mowed 2-3 times per year and the biomass is raked and baled. Weeds are managed using rotary hoeing and row cultivation until crop canopy closure. The organic pasture system is maintained through mowing at appropriate intervals per local organic practices, and biomass is not removed. Agronomic practices for the C-S system are typical for this region and soil type, including chisel plow tillage. Urea ammonium nitrate (UAN) liquid fertilizer is sidressed using a spoke injector in late spring (June 8, 2012; June 11, 2013; June 16, 2014) 3 weeks after corn planting at a rate of $171 \mathrm{kgN} / \mathrm{ha}$. Phosphorus and $\mathrm{K}$ fertilizer are applied in the fall at rates based on soil test results. Weeds are managed with herbicides. Insects and diseases, if encountered, are managed based on Iowa State University recommended treatment rates and application intervals.

Water sampling and analysis: Subsurface drainage water from each plot is collected in dedicated sumps with a pump that empties the sump whenever the water level exceeds a preset level. Only the center drainage line under each plot is monitored for drainage volume and $\mathrm{NO}_{3}-\mathrm{N}$ concentration. Subsurface drainage water $\mathrm{N}$ loss is estimated from flow proportional water samples taken from the drainage water sampling systems (Bjorneberg et al., 1996). Collection of subsurface drainage water flow data began in December 2011 and evaluation of subsurface drainage water quality was initiated in the spring of 2012. Subsurface drainage water flow is recorded every 30 minutes and the electronic data are supplemented with weekly manual meter readings. Subsurface drainage water sub-samples for measuring $\mathrm{NO}_{3}-\mathrm{N}$ concentration are taken every week when the subsurface drains are flowing and analyzed for $\left(\mathrm{NO}_{3}+\mathrm{NO}_{2}\right)$ using a colorimetric method and flow injection technology (Lachat Instruments, Milwaukee, WI). Nitrogen loading loss in the drainage water is calculated using subsurface drainage flow volume and $\mathrm{NO}_{3}-\mathrm{N}$ concentrations and are expressed as $\mathrm{kg} \mathrm{N} \mathrm{ha}^{-1}$. Annual system-wide results were calculated as the mean of the average annual flow-weighted $\mathrm{NO}_{3}-\mathrm{N}$ concentration or as the sum of the average annual $\mathrm{N}$ loss for each phase of the rotation.

\section{Results}

\subsection{Rainfall and Temperature}

Rainfall and ambient temperature patterns across the growing season (March-October) for each of the three years of the study were dramatically different (Table 1). Average annual growing season precipitation for Boone IA is $75.8 \mathrm{~cm}$, with $62.8 \%$ of the rainfall occurring between May and August. An unusually dry and warm spring followed by a dry, hot summer in 2012 was accompanied by nearly $50 \%$ less rainfall $(45.9 \mathrm{~cm})$ than average during this time period. Overall, 2013 growing season precipitation was lower $(57.2 \mathrm{~cm})$ than the 30 -yr growing season average. Higher than average rainfall amounts, accompanied by cooler temperatures, were observed in March, April and May 2013 but the remainder of the 2013 growing season was drier than average. In 2014, growing season rainfall $(86.0 \mathrm{~cm}$ ) exceeded the 30 -yr growing season average and $\sim 25 \%$ of the total growing season precipitation fell during the month of June. In addition, temperatures were cooler than average.

Table 1. Average monthly growing season rainfall $(\mathrm{cm})$ and temperature $\left({ }^{\circ} \mathrm{C}\right)$

\begin{tabular}{lllllllll}
\hline & $2012 \dagger$ & \multicolumn{3}{c}{2013} & & 2014 & \multicolumn{2}{c}{30 -yr Average $\dagger$} \\
\hline March & Temp & Rain & Temp & Rain & Temp & Rain & Temp & Rain \\
April & 10.6 & 5.5 & -1.8 & 3.1 & -1.4 & 1.5 & 2.1 & 5.3 \\
May & 11.4 & 9.9 & 6.8 & 13.1 & 8.5 & 11.6 & 9.2 & 8.7 \\
June & 18.9 & 4.1 & 14.9 & 16.5 & 16.1 & 8.8 & 15.2 & 11.7 \\
July & 22.3 & 6.9 & 20.9 & 7.2 & 21.0 & 22.2 & 20.4 & 12.8 \\
August & 25.4 & 3.1 & 22.6 & 2.5 & 20.3 & 5.4 & 22.8 & 11.9 \\
September & 20.9 & 7.1 & 22.2 & 5.3 & 21.6 & 19.6 & 21.8 & 11.2 \\
October & 16.5 & 4.3 & 19.1 & 3.3 & 16.4 & 9.7 & 17.2 & 7.7 \\
\hline
\end{tabular}

$\dagger$ On-site weather station. \$ Boone, IA USA (NOAA, verified 2/13/15). 


\subsection{Crop Yield}

Organic and conventional corn and soybean yields and organic oat yields were similar to county-wide average yields for Boone County IA in 2012 (Table 2), despite reduced rainfall from May-August. A cool, wet spring followed by a dry summer in 2013 contributed to lower than county average grain yields for conventional and organic corn and soybean. Organic corn yields were especially impacted by the weather conditions in 2013 . Yields for organic corn were $\sim 30 \%$ lower than the county wide average yield for corn. In 2014, organic soybean yield was higher than the county wide average and organic oat yields were nearly twice as high as the county wide average (Table 2). The highest soybean yields for the three year study period were observed in 2014 when organic and conventional soybean yields were similar. Corn yield in 2014 did not differ for the conventional and organic systems and yield from both systems was more than $35 \%$ lower than the county-wide average.

Table 2. Grain yield

\begin{tabular}{llll}
\hline Cropping System & \multicolumn{3}{c}{ Grain Yield $\left(\mathrm{Mg} \mathrm{ha}^{-1}\right)$} \\
\hline Organic Corn & $\mathbf{2 0 1 2}$ & $\mathbf{2 0 1 3}$ & $\mathbf{2 0 1 4}$ \\
Conventional Corn & $9.24(1.0) \dagger$ & $7.14(0.6)$ & $7.91(1.0)$ \\
County Average Corn & $9.79(0.9)$ & $9.04(1.0)$ & $7.64(1.4)$ \\
Organic Soybean & $9.99 \dagger$ & 10.50 & 12.30 \\
Conventional Soybean & $3.06(0.3)$ & $2.24(0.1)$ & $3.84(0.4)$ \\
County Average Soybean & $3.86(0.5)$ & $2.17(0.3)$ & $3.68(0.4)$ \\
Organic Oats & 3.06 & 2.79 & 3.44 \\
County Average Oats & $4.28(0.6)$ & $4.96(0.5)$ & $6.80(0.5)$ \\
\hline
\end{tabular}

$\dagger$ Mean of 5 field replicates (Standard deviation). $\$$ www.nass.gov for Boone County IA USA.

\subsection{Subsurface Drain Flow}

Cumulative average subsurface drain flow in 2012 in the organic C-S-O/A-A (67,006 liters) and the conventional C-S (75,747 liters) systems was similar and an order of magnitude lower than in the organic pasture plots (230,891 liters). Subsurface drain flow did not correlate with precipitation in 2012, except for a sharp peak in flow in mid-April for all cultivated plots (Figure 1a and Table 1). In 2013, cumulative average subsurface drain flow was similar for the three systems: conventional C-S (170,096 liters); organic C-S-O/A-A (192, 839 liters); and organic pasture (179,333 liters). Three large and distinct peaks in flow occurred for all the cropping systems in 2013, and the relationship between peak flow and rainfall amounts was much more evident than in 2012 (Fig $1 \mathrm{~b}$ and Table 1). Cumulative average subsurface drain flow for the conventional C-S (203,948 liters) and organic C-S-O/A-A (207,507 liters) systems were similar in 2014 and twice as great as flow for organic pasture (100, 570 liters). Subsurface drain flow peaked for all three systems in July 2014 following $22.2 \mathrm{~cm}$ of rain in June and peaked again in late August-early September following $19.6 \mathrm{~cm}$ of rain in August (Figure 1c and Table 1). 


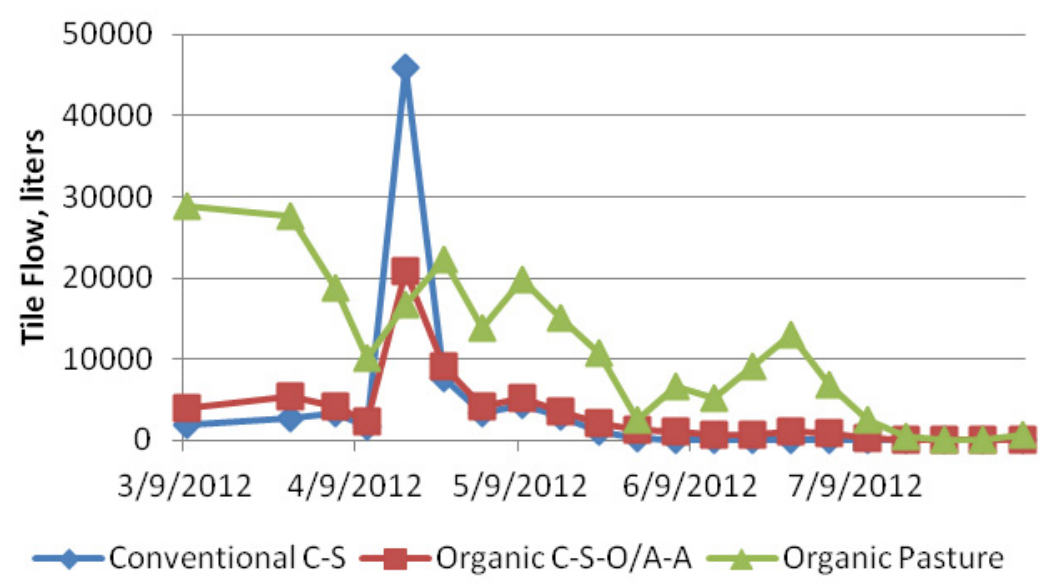

Figure 1a. Subsurface drainage water flow 2012

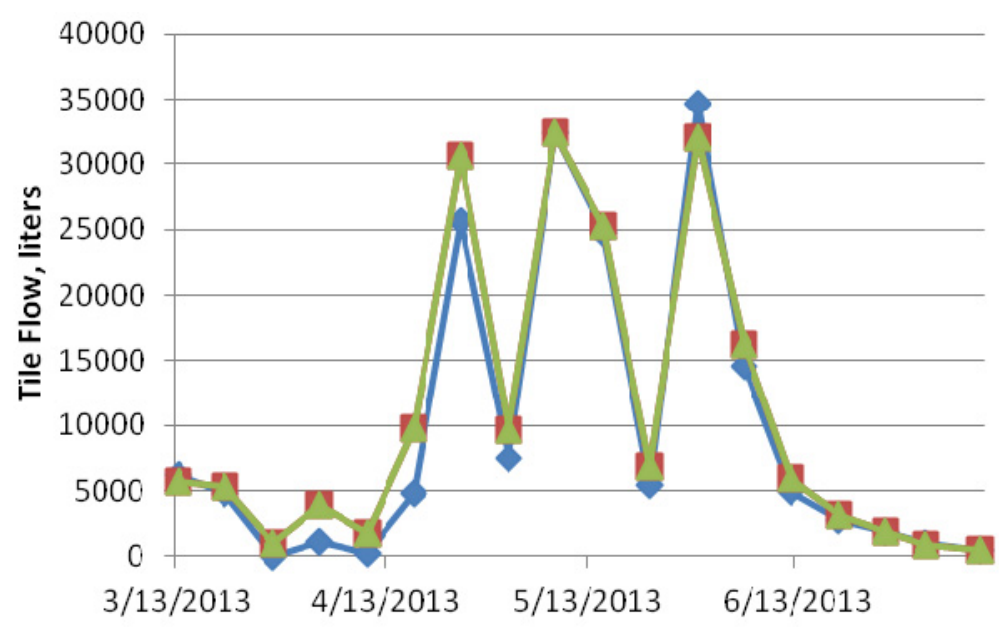

$\rightarrow$ Conventional C-S $\rightarrow$-Organic C-S-O/A-A $\rightarrow$ Organic Pasture

Figure 1b. Subsurface drainage water flow 2013

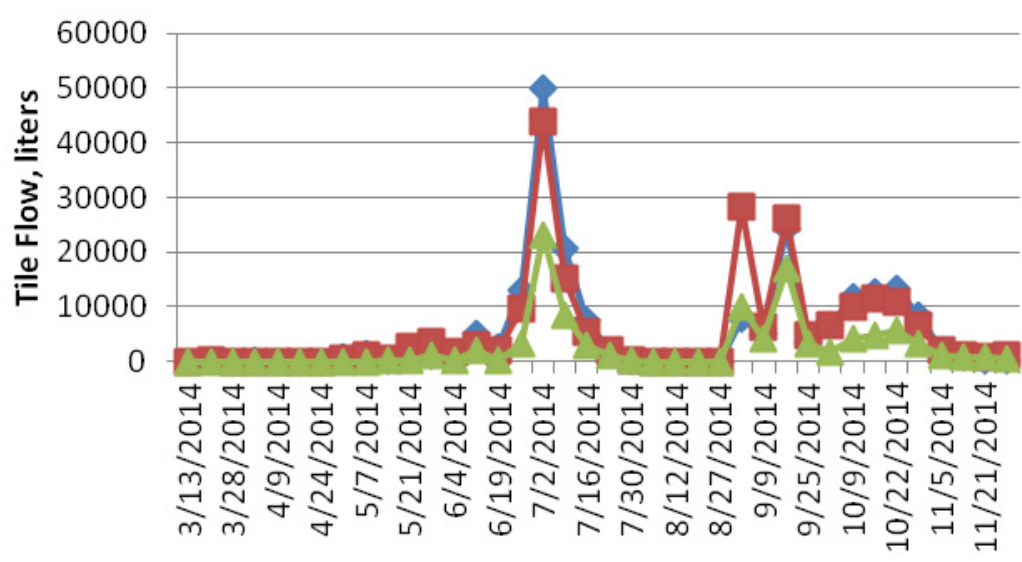

$\longrightarrow$ Conventional C-S - Organic C-S-O/A-A $\longrightarrow$ Organic Pasture

Figure 1c. Subsurface drainage water flow 2014 


\subsection{Subsurface Drainage Water $\mathrm{NO}_{3}-\mathrm{N}$ Concentrations}

Subsurface drainage water $\mathrm{NO}_{3}-\mathrm{N}$ concentrations differed among the three cropping systems and varied across the three years of this study. Flow weighted $\mathrm{NO}_{3}-\mathrm{N}$ concentrations were generally lowest for the pasture and highest for the conventional C-S system for all three years (Figure 2a-2c and Table 3). In the first growing season after subsurface drain installation, $\mathrm{NO}_{3}-\mathrm{N}$ concentration in subsurface drainage water trended down from spring into early summer for the two grain cropping systems but not for the pasture system. Nitrate-N concentrations increased after fertilizer application for the conventional C-S rotation (Figure 2a) and remained high until subsurface drain flow ceased in early August 2012 (Figure 1a). In March 2013, subsurface drainage water $\mathrm{NO}_{3}-\mathrm{N}$ concentrations were less than $5 \mathrm{mg} \mathrm{N}$ liter ${ }^{-1}$ for all three systems, rapidly increased to a maximum of $\sim 35$ $\mathrm{mg} \mathrm{N}$ liter $^{-1}$ and $\sim 15 \mathrm{mg} \mathrm{N}^{-1}$ liter $^{-1}$ in the conventional C-S and organic C-S-O/A-A systems (Figure 2b), respectively, and remained high in the conventional C-S system until flow ceased in early August 2013 (Figure 1b). A similar pattern for subsurface drainage water flow and flow weighted $\mathrm{NO}_{3}-\mathrm{N}$ concentrations for the three cropping systems was observed for spring through mid-August during the 2014 growing season (Figure 2c). Unlike 2013, subsurface drain flow continued into mid-November in 2014 (Figure 1c).

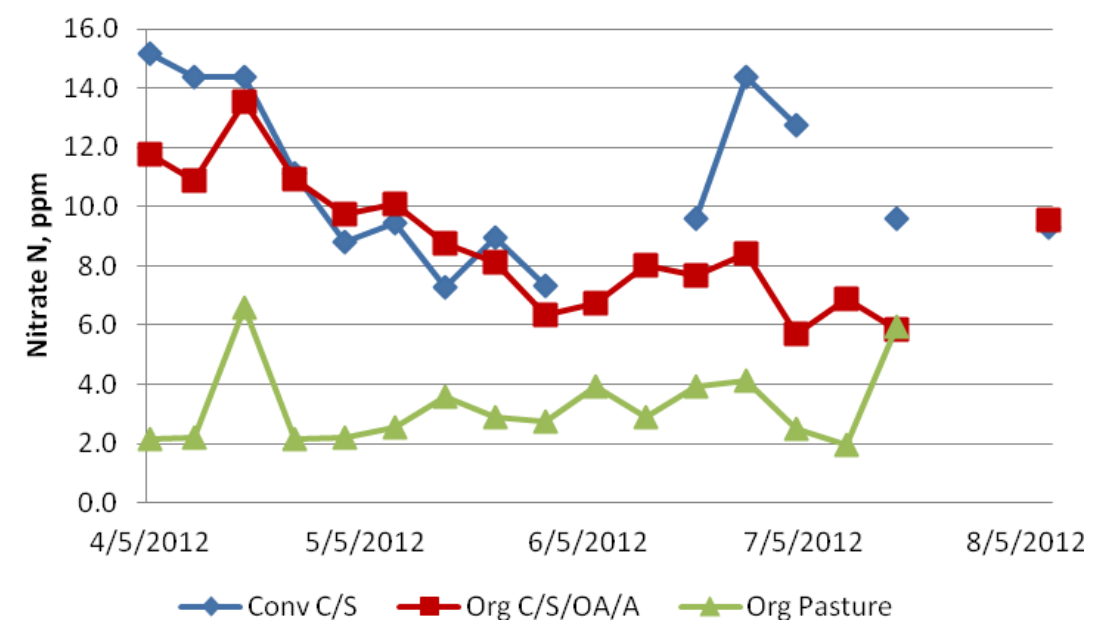

Figure 2a. Flow-weighted subsurface drainage water $\mathrm{NO}_{3}-\mathrm{N}$ concentrations 2012

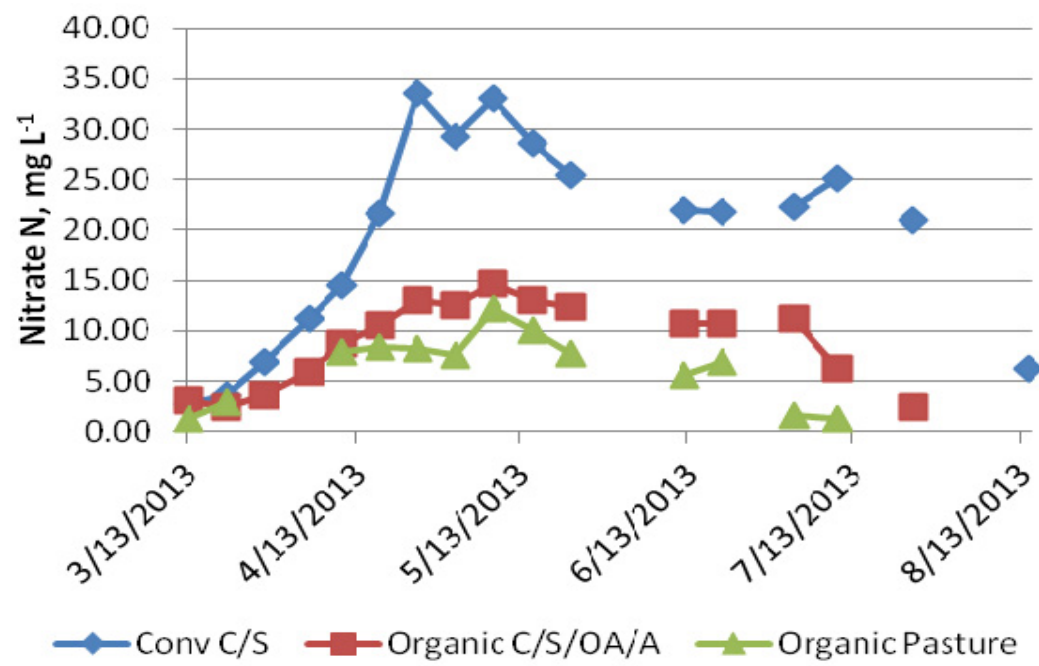

Figure 2b. Flow-weighted subsurface drainage water $\mathrm{NO}_{3}-\mathrm{N}$ concentrations 2013 


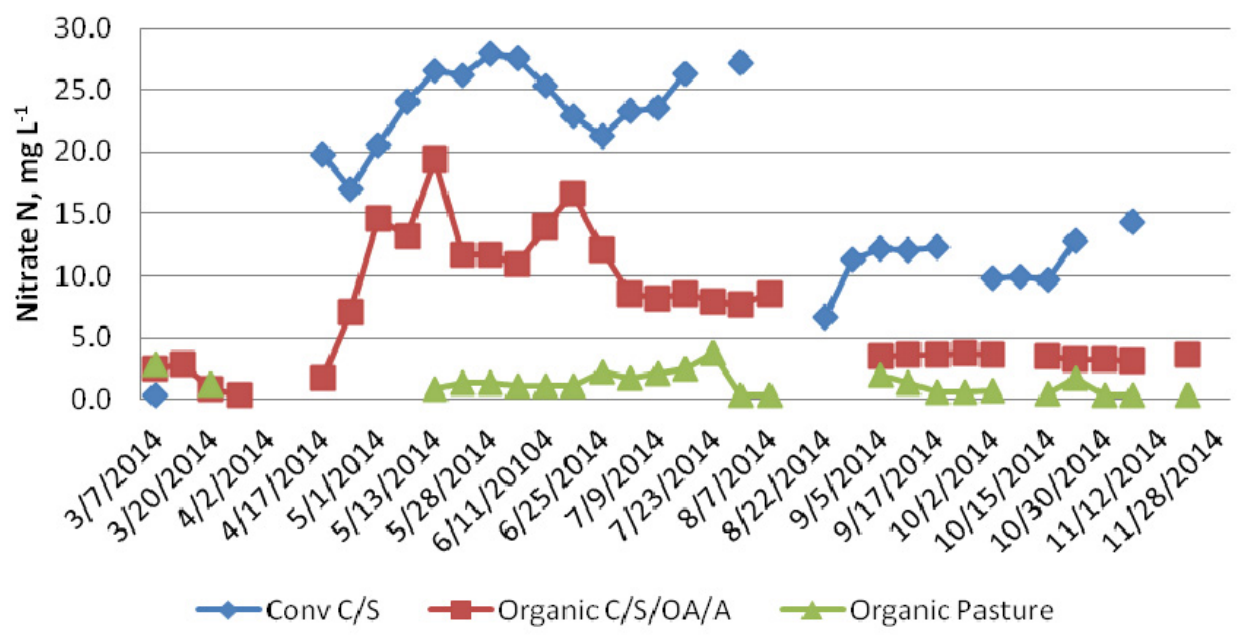

Figure 2c. Flow-weighted subsurface drainage water $\mathrm{NO}_{3}-\mathrm{N}$ concentrations 2014

Subsurface drainage water $\mathrm{NO}_{3}-\mathrm{N}$ concentrations were higher than $\sim 10 \mathrm{mg} \mathrm{N}^{-1} \mathrm{lter}^{-1}$ in the conventional C-S system and less than $5 \mathrm{mg} \mathrm{N}$ liter $^{-1}$ in the organic C-S-O/A-A rotation from early September through November (Figure 2c). During the winter of 2014/2015 subsurface drains continued to flow, and $\mathrm{NO}_{3}-\mathrm{N}$ concentrations were consistently higher for conventional C-S than for the organically managed C-S-O/A-A rotation. Average subsurface drainage water $\mathrm{NO}_{3}-\mathrm{N}$ concentration from November 28, 2014 through February 9, 2015 was 12.9, 3.6 and $0.4 \mathrm{mg} \mathrm{L}^{-1}$ for conventional C-S, organic C-S-O/A-A and organic pasture, respectively.

\subsection{Subsurface Drainage Water $\mathrm{NO}_{3}$-N Loading Loss}

Subsurface drainage water $\mathrm{NO}_{3}-\mathrm{N}$ loading loss for the entire 3-year period from the conventional C-S system $\left(79.2 \mathrm{kgN} \mathrm{ha}^{-1}\right)$ was nearly twice as much as the $\mathrm{N}$ loss from the organic C-S-O/A-A system $\left(39.9 \mathrm{kgN} \mathrm{ha}^{-1}\right)$. The 3 -year $\mathrm{N}$ losses represent $5.8 \%$ of applied $\mathrm{N}$ in the organic rotation and $15.4 \%$ of applied $\mathrm{N}$ in the conventional rotation. The pasture system $\left(16.5 \mathrm{kgN} \mathrm{ha}^{-1}\right)$ lost the least amount of $\mathrm{N}$ over the 3 years. Subsurface drainage water N loss for 2012 was much lower than 2013 and 2014 for the conventional and organic crop rotations and the difference in $\mathrm{N}$ loss between the two systems was the smallest in 2012 (Table 3). The conventional C-S system lost $100 \%$ and $132 \%$ more $\mathrm{NO}_{3}-\mathrm{N}$ in subsurface drainage water than the organic C-S-O/A-A system in 2013 and 2014, respectively.

Table 3. Flow-weighted annual subsurface drainage water $\mathrm{NO}_{3}-\mathrm{N}$ concentration and annual nitrate-N loss

\begin{tabular}{lll}
\hline Cropping System & $\mathbf{N O}_{3}-\mathbf{N ~ C o n c e n t r a t i o n ~}\left(\mathbf{m g N ~ l i t e r}{ }^{-1}\right)$ & $\mathbf{N O}_{3}-\mathbf{N ~ L o s s}\left(\mathbf{k g N ~ h a}^{-1}\right)$ \\
\hline $\mathbf{2 0 1 2}$ & & $7.7(0.9) \dagger$ \\
Organic C-S-O/A-A & $8.8(2.2) \dagger$ & $10.1(2.2)$ \\
Conventional C-S & $10.9(2.8)$ & $5.8(3.6)$ \\
Organic Pasture & $3.3(1.4)$ & \\
$\mathbf{2 0 1 3}$ & & $17.7(6.3)$ \\
Organic C-S-O/A-A & $8.8(4.2)$ & $34.7(14.0)$ \\
Conventional C-S & $19.4(10.1)$ & $9.5(7.5)$ \\
Organic Pasture & $6.3(3.5)$ & $14.5(5.7)$ \\
$\mathbf{2 0 1 4}$ & & $34.4(9.6)$ \\
Organic C-S-O/A-A & $7.2(5.0)$ & $1.2(1.3)$ \\
Conventional C-S & $18.1(7.8)$ & \\
Organic Pasture & $1.3(0.9)$ &
\end{tabular}

$\dagger$ Mean of 5 field replicates (Standard deviation). 


\section{Discussion}

Nitrate-N contamination of surface water is a major water quality concern in the upper Midwest USA. Environmental impacts associated with agricultural production have encouraged producers to investigate alternative management practices, including organic farming methods. Mechanisms underlying improved environmental conditions on organic farms have included an improved capacity for greater water and soil nutrient retention due to enhanced soil organic matter content from more diverse crop sequences and application of organic-based amendments, including cover crops and manure (Liebig \& Doran, 1999). This study quantified growing season subsurface drainage water nitrate-N losses for conventional and organic grain cropping systems from 2012-2014. Subsurface drainage water was isolated from each plot by installing subsurface drain pipes under and between each plot and around the entire perimeter of the experimental site. The experimental approach used in this study is rare in the literature because of the high cost of establishing subsurface drainage water monitoring infrastructure.

Average cumulative growing season $\mathrm{NO}_{3}-\mathrm{N}$ loss for the C-S-O/A-A system for 2012-2014 was $13.3 \mathrm{~kg} \mathrm{~N} \mathrm{ha}{ }^{-1}$. The magnitude of $\mathrm{N}$ loss from the organic system in our study is similar to $\mathrm{N}$ loss from organic corn-soybean rotations in PA, USA $\left(17 \mathrm{~kg} \mathrm{~N} \mathrm{ha}^{-1}\right.$ ) (Pimentel et al., 2005) and lower than $\mathrm{N}$ losses reported for organic small grain based rotations in Denmark (26-106 kg N ha ${ }^{-1}$ )(Askegaard et al., 2005), Germany $\left(20.7 \mathrm{~kg} \mathrm{~N}^{-1}\right)^{-1}$ (Loges et al., 2008) and the UK (55.9-93.9 $\left.\mathrm{kgN} \mathrm{ha}^{-1}\right)($ Hatch et al., 2010). Subsurface drainage water nitrate-N loss for the 3 -year period from the conventionally managed C-S system $(79.2 \mathrm{kgN} / \mathrm{ha})$ was nearly twice as much as from the organically managed C-S-O/A-A (39.9 kgN/ha). Research conducted in Norway on loamy and silty sand soils showed that $42 \%$ more nitrogen was lost in subsurface drainage from conventionally farmed land than from organic land (Korsaeth \& Eltun, 2000).

Results of this study suggest that organic farming practices, such as the application of composted animal manure and the use of forage legumes and green manures within extended cropping rotations, can improve water quality in Midwestern subsurface-drained landscapes.

\section{Acknowledgments}

This research was funded by USDA-ARS-National Laboratory for Agriculture and the Environment (NLAE), a grant from USDA-CSREES-Integrated Organic and Water Quality Program-002403, and the Iowa State University Organic Agriculture Program. We thank the farming and field support staff at the NLAE, especially Jared Flater, Kent Heikens, and Derek Carney; the farming support staff at the NLAE, especially Rich Hartwig, Ben Knutson and Keith Kohler; and the laboratory and analytical support staff at the NLAE, especially Jody Ohmacht and Amy Morrow.

\section{References}

Askegaard, M., Olesen, J. E., \& Kristensen, K. (2005). Nitrate leaching from organic arable crop rotations: Effects of location, maure and catch crop. Soil Use and Management, 21, 181-188. http://dx.doi.org/10.1111/j.1475-2743.2005.tb00123.x

Baker, J. L., \& Johnson, H. P. (1981). Nitrate-nitrogen in tile drainage as affected by fertilization. J. Environ. Qual, 10, 519-522. http://dx.doi.org/10.2134/jeq1981.00472425001000040020x

Biro, B., Varga, G., Hartl, W., \& Nemeth, T. (2005). Soil quality and nitrate percolation as affected by the horticultural and arable field conditions of organic and conventional agriculture. Acta Agriculturae Scandinavica Section B- Soil and Plant Science, 55, 111-119. http://dx.doi.org/10.1080/09064710510029033

Bjorneberg, D. L., Kanwar, R. S., \& Melvin, S. W. (1996). Seasonal changes in flow and nitrate-N loss from subsurface drains. Trans. Am. Soc. Agric. Eng, 39, 961-976. http://dx.doi.org/10.13031/2013.27582

Boody, G., Vondracek, B., Andow, D. A., Krinke, M., Westra, J., Zimmerman, J., \& Welle, P. (2005). Multifunctional agriculture in the United States. Bioscience, 55, 27-38. http://dx.doi.org/10.1641/0006-3568(2005)055\%5B0027:MAITUS\%5D2.0.CO;2

Cambardella, C. A., Moorman, T. B., Jaynes, D. B., Parkin, T. B., Simpkins, W. W., \& Karlen, D. L. (1999). Water quality in Walnut Creek watershed: Nitrate-nitrogen in soils, subsurface drainage water and shallow groundwater. J. Environ. Qual, 28, 25-34. http://dx.doi.org/10.2134/jeq1999.00472425002800010003x

Delate, K., \& Cambardella, C. A. (2004). Agroecosystem performance during transition to organic grain production. Agronomy J, 96, 1288-1298. http://dx.doi.org/10.2134/agronj2004.1288

Dinnes, D. L., Karlen, D. L., Jaynes, D. B., Kaspar, T. C., Hatfield, J. L., Colvin, T. S., \& Cambardella, C. A. 
(2002). Nitrogen management strategies to reduce nitrate leaching in tile-drained Midwestern soils. Agronomy J., 94, 153-171. http://dx.doi.org/10.2134/agronj2002.0153

Gast, R. G., Nelson, W. W., \& Randall, G. W. (1978). Nitrate accumulation in soils and loss in tile drainage following nitrogen application to continuous corn. J. Environ. Qual, 7, 258-262. http://dx.doi.org/10.2134/jeq1978.00472425000700020021x

Goolsby, E. A., Battaglin, W. A., Lawrence, G. B., Artz, R. S., Aulenbach, B. T., Hooper, R. P., ... Stensland, F. J. (1999). Flux and sources of nutrients in the Mississippi-Atchafalaya river basin: Topic 3 Report for the Integrated Assessment of Hypoxia in the Gulf of Mexico.

Hansen, B., Kristensen, E. S., Grant, R., Høgh-Jensen, H., Simmelsgaard, S. E., \& Olesen, J. E. (2000). Nitrogen leaching from conventional versus organic farming systems- a systems modelling approach. European $J$. Agron, 13, 65-82. http://dx.doi.org/10.1016/S1161-0301(00)00060-5

Hatch, D. J., Joynes, A., \& Stone, A. (2010). Nitrogen uptake in organically managed spring sown lupins and residual effects on leaching and yield of a following winter cereal. Soil Use and Management, 26, 21-26. http://dx.doi.org/10.1111/j.1475-2743.2009.00252.x

Jaynes, D. B., Colvin, T. S., Karlen, D. L., \& Cambardella, C. A. (2001). Nitrate loss in subsurface drainage as affected by N fertilizer rate. J. Environ. Qual, 30, 1305-1314. http://dx.doi.org/10.2134/jeq2001.3041305x

Jaynes, D. B., Hatfield, J. L., \& Meek, D. W. (1999). Water quality in Walnut Creek watershed: Herbicides and $\begin{array}{llllll}\text { nitrate in surface waters. } J \text {. Environ. } & \text { Qual, }\end{array}$ http://dx.doi.org/10.2134/jeq1999.00472425002800010005x

Korsaeth, A., \& Eltun, R. (2000). Nitrogen mass balances in conventional, integrated, and ecological cropping systems and the relationship between balance calculations and nitrogen runoff in an 8-yr field experiment in Norway. Agric. Ecosyst. Environ, 79, 199-214. http://dx.doi.org/10.1016/S0167-8809(00)00129-8

Liebig, M. A., \& Doran, J. W. (1999). Impact of organic production practices on soil quality indicators. $J$. Environ. Qual, 28, 1601-1609. http://dx.doi.org/10.2134/jeq1999. 00472425002800050026x

Loges, R., Kelm, M., \& Taube, F. (2008). Nitrate leaching and energy efficiency of stockless arable systems compared with mixed farming and a non-organic system on fertile soils in Northern Germany. Cultivating the Future Based on Science: 2nd Conference of the International Society of Organic Agriculture Research ISOFAR, Modena, Italy, June 18-20. http://orgprints.org/12256

Magner, J. A., Paybe, G. A., \& Steffen, L. J. (2004). Drainage effects on stream nitrate-N and hydrology in south-central Minnesota (USA). Environ. Monit. Assess, 91, 183-198. http://dx.doi.org/10.1023/B:EMAS.0000009235.50413.42

Oquist, K. A., Strock, J. S., \& Mulla, D. J. (2007). Influence of alternative and conventional farming practices on subsurface drainage and water quality. J. Environ. Qual, 36, 1194-1204. http://dx.doi.org/10.2134/jeq2006.0274

Pimentel, D., Culliney, T. W., Butler, I. W., Reinemann, D. J., \& Beckman, K. B. (1989). Low-input sustainable agriculture using ecological management practices. Agric. Ecosyst. Environ, 27, 3-24. http://dx.doi.org/10.1016/0167-8809(89)90068-6

Pimentel, D., Hepperly, P., Hanson, J., Douds, D., \& Seidel, R. (2005). Environmental, energetic, and economic comparisons of organic and conventional farming systems. BioScience, 55, 573-582. http://dx.doi.org/10.1641/0006-3568(2005)055\%5B0573:EEAECO\%5D2.0.CO;2

Rabalais, N. N, Wiseman, W. J., Turner, R. E., Sen Gupta, B. K., \& Dortch, Q. (1996). Nutrient changes in the Mississippi River and system responses on the adjacent continental shelf. Estuaries, 19, 386-407. http://dx.doi.org/10.2307/1352458

Randall, G. W., Huggins, D. R., Russelle, M. P., Fuchs, D. J., Nelson, W. W., \& Anderson, J. L. (1997). Nitrate losses through subsurface tile drainage conservation reserve program, alfalfa, and row crop systems. $J$. Environ. Qual, 26, 1240-1247. http://dx.doi.org/10.2134/jeq1997. 00472425002600050007x

Stopes, C., Lord, E. I., Philipps, L., \& Woodward, L. (2002). Nitrate leaching from organic farms and conventional farms following best practice. Soil Use and Management, 18, 256-263. http://dx.doi.org/10.111/j.1475-2743.202.tb00267.x 
Zhao, S. L., Gupta, S. C., Huggins, D. R., \& Moncrief, J. R. (2001). Tillage and nutrient source effects on surface and subsurface water quality at corn planting. J. Environ. Qual, 30, 998-1008. http://dx.doi.org/10.2134/jeq2001.303998x

\section{Copyrights}

Copyright for this article is retained by the author(s), with first publication rights granted to the journal.

This is an open-access article distributed under the terms and conditions of the Creative Commons Attribution license (http://creativecommons.org/licenses/by/3.0/). 